\title{
UPAYA PERPUSTAKAAN UNIVERSITAS AIRLANGGA DALAM MEWUJUDKAN AIRLANGGA UNIVERSITY LIBRARY SUSTAINABLE DEVELOPMENT GOALS (SDGs)
}

\author{
Suhernik \\ Perpustakaan Universitas Airlangga \\ suhernik@staf.unair.ac.id \\ Indah Rachma Cahyani \\ Perpustakaan Universitas Airlangga \\ indah.rachma@staf.unair.ac.id
}

\begin{abstract}
ABSTRAK
Saat ini perpustakaan umum, perpustakaan nasional, universitas, sekolah, dan khusus memastikan bahwa informasi dan keterampilan untuk menggunakan informasi tersedia untuk semua pemustaka dan menjadikan institusi bagian dari revolusi era digital. Perpustakaan menyediakan infrastruktur teknologi informasi dan komunikasi (TIK), membantu pemustaka mengembangkan kapasitas untuk menggunakan informasi secara efektif, dan melestarikan informasi untuk memastikan akses berkelanjutan bagi generasi mendatang. Kajian ini bertujuan untuk menggambarkan strategi Perpustakaan Universitas Airlangga dalam dalam mewujudkan Airlangga University Library Sustainable Development Goals (SDGs), dengan metode studi literature, kajian ini mampu menampilkan konsep-konsep secara detail dan mampu membuat kerangka berfikir khususnya dalam hal mengatur dan memilih mana referensi yang relevan dengan kajian yang dibuat.
\end{abstract}

Kata kunci: perpustakaan, universitas airlangga, sustainable development goals, perguruan tinggi

\section{PENDAHULUAN}

Perpustakaan saat ini telah berkembang menyediakan jaringan institusi lokal yang mapan dan tepercaya yang secara efektif menjangkau sesuatu yang baru dari yang sebelumnya sempat terpinggirkan.Akses informasi adalah masalah lintas sektor yang mendukung semua SDG atau Sustainable Development Goals.Layanan perpustakaan berkontribusi pada peningkatan hasil pada tujuan Sustainable Development Goals (SDG) dengan mempromosikan literasi universal, termasuk literasi media dan informasi. Keterampilan literasi digital mampu menjadi penutup kesenjangan dalam akses ke informasi dan membantu pemerintah, masyarakat sipil dan bisnis untuk lebih memahami kebutuhan informasi lokal seperti menyediakan jaringan situs untuk program dan layanan pemerintah, memajukan inklusi digital melalui akses ke TIK (Nasrullah et al., 2017), dan pustakawan yang berdedikasi untuk membantu pemustaka mengembangkan keterampilan digital baru yang dapat berperan sebagai jantung dari penelitian dan komunitas akademis. 
Perpustakaan dapat mendukung implementasi SDGs dengan menyediakan akses informasi, dukungan untuk literasi dan keterampilan TIK, dan akses ke ruang komunitas, beberapa contohnya adalah perpustakaan sebagai tempat penyimpanan informasi yang mendukung penyebaran informasi dan penelitian untuk membantu pengambil keputusan.Penerapan teknologi informasi dan komunikasi (TIK) untuk layanan perpustakaantelah meningkatkan kapasitas perpustakaan akademik ke tingkat pengetahuan yang belum pernah terjadi sebelumnyapengelolaan dan penyebaran informasi di luar dinding fisik perpustakaan. Perpustakaan perguruan tinggi memainkan peran penting dalam pengetahuanmanajemen yang penting untuk transformasi informasi dan modal intelektualdiperlukan untuk pencapaian SDGs. Akademisi adalah pencipta pengetahuan terbaiksementara perpustakaan perguruan tinggi dan pustakawan adalah pemain utama dalammanajemen pengetahuan (Anasi et al., 2018).

Perpustakaan perguruan tinggi abad kedua puluh satu telah menyaksikan paradigma yang luar biasa bergeser dan menjadi ruang hibrida yang mengintegrasikan aktivitas baru yang didukung oleh jaringanteknologi digital berdampingan dengan model tradisional, selain melayani sebagai "jantung intelektual" perpustakaan adalah pusat teknologi yang mampu menjembatani kesenjangan digital danmempercepat pencapaian tujuan pembangunan berkelanjutan (SDGs). Perpustakaan perguruan tinggi sebagai pusat di mana orang datang untuk mengakses sumber daya dan berinteraksi dengan orang lain, juga bisa bertindak sebagai katalis atau saluran yang mampu menghubungkan berbagai kelompok dan organisasi sosial,dan menghubungkan praktik kreatif dan komunitas yang berbeda.

Universitas dan organisasi penelitian sebagai pusat pengetahuan dangudang pengetahuan,mendukung pandangan ini, (Hayes, 2004) berpendapat bahwa perguruan tinggi dapat dipandang sebagai pabrik pengetahuan yang menciptakan pengetahuan barumelalui penelitian dan dengan mendidik pekerja pengetahuan, keduanya penting untuk ekonomi modern; dimungkinkan dengan dukungan dari para pustakawan yang memainkannyaperan tradisional untuk memperoleh, mengorganisir dan menyebarkan pengetahuan di antara para anggotakomunitas universitas untuk mempromosikan kegiatan penelitian yang berkontribusi tidak hanyamenuju pembangunan masyarakat pengetahuan dan ekonomi pengetahuan tetapi juga meningkatkan pencapaian SDGs. Perpustakaan universitas juga sebagai pusat pengetahuanmenyediakan platform untuk generasi, dan penyebaran pengetahuan dan iniadalah katalis penting untuk mempercepat pencapaian agenda SDG di semua tingkatan.

Perpustakaan memainkan peran penting dalam menyediakan akses ke data, penelitian, dan pengetahuan yang mendukung penelitian yang terinformasi dan akses informasi ke publik, sehingga kajian bertujuan untuk mengetahui bagaimana upaya dan strategi Perpustakaan Universitas Airlangga dalam mewujudkan Sustainable Development Goals (SDGs) di era pesatnya kemajuan tekonologi, manfaat dari kajian ini adalah menambah pengetahuan dan wawasan pustakawan dan perpustakaan dalam mewujudkan percepatan Sustainable Development Goals (SDGs) dengan segala bentuk sumber daya yang dimiliki perpustakaan.

\section{TINJAUAN PUSTAKA}

Peneliti melakukan telaah terhadap beberapa kajian yang memiliki keterkaitan dengan kajian yang peneliti lakukan, penelitian oleh (Fatmawati, 2018) menyebutkan bahwa, 
Multikompetansi senantiasa perlu diperbarui dan ditingkatkan dalam upaya menunjang pembangunan nasional, hal ini menjadi perlu diberlakukan pada pustakawan untuk berperan dalam pembangunan nasional secara berkelanjutan atau yang biasa disebut dengan Sustainable Development Goals (SDGs). Multi-kompetensi yang harus dimiliki oleh pustakawan meliputi kompetensi hard dan soft, penguasaan dalam teknologi informasi dan komunikasi (TIK), memiliki kecerdasan, menulis karya ilmiah, literasi informasi, dan literasi media. Penelitian lain yang dilakukan oleh (Rufaidah\&Iskak, 2019) menyebutkan bahwa sebagai perpustakaan khusus yang berada lingkungan Kementerian berperan dalam mendukung pencapaian visi lembaga induk, Kementerian tersebut, PUSTAKA adalah perpustakaan khusus dilingkungan kementerian pertanian mempunyai visi dan misi yang selaras dengan Kementerian Pertanian. Tercapainya visi Kementerian Pertanian, dengan sendirinya akan pula tercapai beberapa indikator SDGs yang terkait dengan pembangunan pertanian, dari penelitian ini dapat dikatakan bahwa perpustakaan yang mampu mencapai indikator SDGs mampu mendukung pembangunan berkelanjutan dalam skala nasional.

Perlu dijelaskan istilah-istilah yang terkait dengan Sustainable Development Goals (SDGs) sangat penting dalam konteks ini karena merupakan jawaban dan cara untuk menyelesaikan masalah organisasi perpustakaan dunia modern, termasuk lingkungan kehidupan manusia. Ide inidimulai pada tahun 1960-an, meskipun definisi SD yang paling sering dikutip muncul dari Laporan Komisi Dunia untuk Lingkungan dan Pembangunan yang menyatakan bahwa pembangunan berkelanjutan adalah pembangunan yang memenuhi kebutuhan saat ini tanpa mengorbankan kemampuan generasi mendatang untuk memenuhi kebutuhan mereka sendiri (Voituriez et al., 2017). Pada 2016, IFLA meluncurkan Program Advokasi Internasional (IAP) yang bertujuan untuk meningkatkan kesadaran pustakawan tentang SDGs, mempromosikan peran perpustakaan dalam perencanaan dan pelaksanaan UN Agenda 2030 dan SDGs serta mendukung akses informasi publik (IFLA, 2018).

Akses informasi merupakan hak asasi manusia yang fundamental dan sumber daya strategis bagi aktualisasi pembangunan berkelanjutan. Perpustakaan adalah satu-satunya pusat pada komunitas dimana tempat individu mengakses informasi yang akan membantu meningkatkan pendidikan pemustaka, memperoleh keterampilan baru, juga membuat keputusan berdasarkan informasi mendapatkan wawasan tentang masalah terkait. Keunikan ini menjadikan perpustakaan dan layanan informasi penting untuk menjembatani kesenjangan digital dan mempercepat aktualisasi SDG. Perpustakaan juga menyediakan akses informasi dalam semua format dan layanan pengiriman yang memenuhi kebutuhan individu dalam masyarakat yang dinamis dan kompleks (Shafack, 2016). Tujuan lain dari perpustakaan adalah melindungi hak pengguna untuk mengakses informasi secara aman. Perpustakaan secara sosial dan budaya inklusif melampaui pendidikan formal, yakni mendorong dan mempertahankan keaksaraan, dan mendukung pengembangan.

(Krolak, 2006) berpendapat bahwa perpustakaan memainkan peran penting dalam penciptaan Lingkungan. Organisasi Pendidikan, Keilmuan, dan Kebudayaan, perpustakaan mendukung masyarakat di mana orang-orang latar belakang apa pun dapat belajar, membuat, dan berinovasi. Perpustakaan mendukung budaya literasi dan menumbuhkan pemikiran kritis, melalui perpustakaan masyarakat dapat memanfaatkan kekuatan internet untuk meningkatkan kehidupan sehingga mempercepat pencapaian SDGs. Informasi dan pengetahuan saat ini sangat diperlukan dalam mendukung pembangunan berkelanjutan dan meningkatkan 
kehidupan masyarakat. Pustakawan sebagai inovator teknologi dan pendidik yang memiliki peran alami dalam menerapkan ICTs ke berbagai jenis literasi dan menjadi penjaga pengetahuan dunia, dengan menggunakan teknologi untuk demokratisasi akses informasi.

\section{METODE PENELITIAN}

Dalam kajian ini penulis menggunakan metode Studi Literatur, dimana metode ini penulis membaca dan memahami berbagai macam buku-buku dan jurnal-jurnal ilmiah baik itu buku yang bersumber dari Buku digital dan jurnal ilmiah yang berasal dari sumber online, thesis, skripsi yang berkaitan dengan upaya Perpustakaan Universitas Airlangga dalam mewujudkan Airlangga University Library Sustainable Development Goals (SDGS). Studi literatur ini sangat berguna dan bermanfaat bagi penulis karena penulis mampu mengetahui konsep-konsep secara detail dan mampu membuat kerangka berfikir khususnya dalam hal mengatur dan memilih mana referensi yang relevan dengan kajian yang dibuat (Koentjaraningrat, 1983).

\section{PEMBAHASAN}

Perpustakaan sebagai pusat informasi memainkan peran penting dalam gerakan berkelanjutan. Beberapa perpustakaan danlayanan informasi akan meningkatkanpencapaian tujuan tersebut dengan beradaptasike peran baru. Perpustakaan perlumengkonsolidasikan layanan yang memfasilitasi implementasi SDGs, namun perlu diperhatikan bahwa upaya perpustakaan untuk mencapai semua tujuan bukan tanpa masalah.Perpustakaan di Indonesia yang notabene sebagai negara berkembang harus mengadopsitujuan-tujuan yang dapat dikelola dengan baikmelalui upaya terkonsentrasi untuk sukses.Salah satu layanan perpustakaan yang harusdikonsolidasikan untuk memastikan pencapaian initujuannya adalah layanan literasi informasi. Aksesibilitas dan pemanfaatan informasielemen penting dalam perkembangan, ada pula bentuk SDGs di Perpustakaan Universitas Airlangga adalah sebagai berikut:

\section{SDG1: NO POVERTY}

\section{Penyelenggaraan Program Pelatihan Dalam Rangka Meningkatkan Akses Layanan Informasi}

Dalam rangka mendukung tujuan pembangunan nasional, perpustakaan menyelenggarakan program pelatihan/workshop untuk meningkatkan akses layanan informasi, yaitu pelatihan manajemen perpustakaan tingkat PAUD, TK, dan Sekolah Dasar sampai tingkat Sekolah Menengah atas pada perpustakaan/taman baca binaan Perpustakaan Universitas Airlangga.

Sejak tahun 2009, Perpustakaan berkomitmen untuk mendirikan perpustakaan atau taman baca di sekitar kampus Universitas Airlangga, yaitu di lembaga/yayasan Pendidikan Anak Usia Dini, Taman Kanak-kanan, dan Pondok Pesantren. Sampai saat ini, terdapat 11 taman baca yang tersebar di kota Surabaya, Malang, Bojonegoro dan Yogyakarta. Kegiatan tersebut dilaksanakan guna mendukung pelaksanaan program Tri Dharma Perguruan Tinggi, khususnya program pengabdian masyarakat. Tujuan dilaksanakan kegiatan pembinaan perpustakaan/taman baca tersebut adalah menciptakan reading habit sejak usia dalam rangka meningkatkan minat baca. 
Tabel 1. Taman Baca Binaan Perpustakaan Universitas Airlangga

\begin{tabular}{|c|c|c|c|}
\hline No & Yayasan/Lembaga Binaan & Pendirian & Lokasi \\
\hline 1 & PAUD Tunas Mandiri & 2009 & Jl. Gubeng Masjid VI/55 Surabaya \\
\hline 2 & TK Islam Nabawi & 2010 & Jl. Jojoran I Blok AB/ 12 Surabaya \\
\hline 3 & Pos PAUD Melati & 2010 & $\begin{array}{l}\text { J1. Kedung Tarukan Baru I No.21, Mojo, Kec. Gubeng, } \\
\text { Kota SBY, Jawa Timur } 60285\end{array}$ \\
\hline 4 & TK Melati Ceria & 2011 & $\begin{array}{l}\text { Jl. Labansari No.91, Dukuh Sutorejo, Kec. Mulyorejo, } \\
\text { Kota SBY, Jawa Timur } 60113\end{array}$ \\
\hline 5 & Panti Asuhan Ashabul Kahfi & 2011 & $\begin{array}{l}\text { Jl. Raya Mulyosari No.57, Kalisari, Kec. Mulyorejo, } \\
\text { Kota SBY, Jawa Timur } 60112\end{array}$ \\
\hline 6 & TK Aisiyah 06 & 2011 & Jl. Mulyorejo No. 100 Surabaya. Kode Pos, : 60115 \\
\hline 7 & TK Handayani & 2011 & $\begin{array}{l}\text { Jl. Pacar Kembang No.77A, Pacar Kembang, Kec. } \\
\text { Tambaksari, Kota SBY, Jawa Timur } 60132\end{array}$ \\
\hline 8 & Ponpes Al Qodir Yogyakarta & 2013 & $\begin{array}{l}\text { Tanjung, RT.004/RW.024, Selorejo, Wukirsari, Kec. } \\
\text { Cangkringan, Kabupaten Sleman, Daerah Istimewa } \\
\text { Yogyakarta 55583 }\end{array}$ \\
\hline 9 & $\begin{array}{l}\text { SMPN } 5 \text { Mandangin } \\
\text { Sampang Madura }\end{array}$ & 2013 & $\begin{array}{l}\text { Dusun Kramat RT. 004/RW. 002, Desa Pulau } \\
\text { Mandangin, Kecamatan Sampang, Kramat, P. } \\
\text { Mandingan, Kec. Sampang, Kabupaten Sampang, Jawa } \\
\text { Timur } 69216\end{array}$ \\
\hline 10 & SDN Tangir I Bojonegoro & 2014 & $\begin{array}{l}\text { Desa Tanggir, Tanggir, Kec. Malo, Kab. Bojonegoro Pro } \\
\text { v. Jawa Timur }\end{array}$ \\
\hline 11 & $\begin{array}{l}\text { SDN I Ngantru Ngantang } \\
\text { Malang }\end{array}$ & 2014 & $\begin{array}{l}\text { Kenteng, Ngantru, Kec. Ngantang, Malang, Jawa Timur } \\
65392\end{array}$ \\
\hline 12 & $\begin{array}{l}\text { Pondok Pesantren Putri } \\
\text { Muhammadiyah Surabaya }\end{array}$ & 2017 & Jl. Kedinding Lor 3-4 Surabaya \\
\hline
\end{tabular}

Program pelatihan/workshop yang diadakan:

1. Pelatihan Pengolahan Buku (klasifikasi)

2. Workshop Storytelling

3. Ketrampilan merajut, membuat bross dari kain, dan ketrampilan membuat alat perga dari kain flannel dll.

Program pelatihan yang dilaksanakan Perpustakaan Universitas Airlangga untuk meningkatkan minat baca, dengan harapan mencetak generasi muda yang cerdas informasi, sehingga mampu meningkatkan kualitas hidup. Perpustakaan telah melakukan kegiatan yang berkaitan dengan semua aspek ESD: lingkungan, sosial danekonomis selama bertahun-tahun, misalnya, tindakan untuk mencegah diskriminasi mengakses informasi dan koleksi, dan perlindungan hak kekayaan intelektual, terlibat dalam menghidupkan kehidupan budaya, pendidikan dan integrasi komunitas lokal, kerjasama dengan otoritas, organisasi dan institusi lokal, menciptakan peluang untuk mengakses teknologi baru, dan memenuhi kebutuhan informasi pemustaka. Beberapa tahun terakhir, perpustakaan semakin menunjukkan perhatiannya dengan meminimalkan dampak negatif melalui pengelolaan perpustakaan yang tepat,bangunan hijau dan sejumlah layanan, program dan proyek yang ditargetkan untuk pengguna,tujuannya adalah untuk meningkatkan kesadaran informasidengan berbagai kegiatan (Fedorowicz-Kruszewska, 2020), selain pada perpustakaan/taman baca binaan, perpustakaan juga menyelenggarakan kegiatan Pelatihan/Worksop Manajemen Perpustakaan bagi para guru pengelola perpustakaan di Jawa Timur dan sekitarnya 
Tabel 2. Pelatihan Manajemen Perpustakaan Sekolah

\begin{tabular}{|c|c|c|}
\hline Pelaksanaan & TOPIK & Keterangan \\
\hline 16 April 2010 & $\begin{array}{l}\text { Perpustakaan Sekolah sebagai layanan } \\
\text { sumber informasi }\end{array}$ & $\begin{array}{l}\text { Diselenggarakan di Perpustakaan } \\
\text { UNAIR dalam rangka peringatan } \\
\text { Dies Natalis Perpustakaan }\end{array}$ \\
\hline $26-27$ Oktober 2010 & Manajemen Otomasi Perpustakaan & $\begin{array}{ll}\text { Diselenggarakan dalam rangka } \\
\text { Dies Natalis UNAIR }\end{array}$ \\
\hline 19-20 Juli 2011 & Pelatihan pengelolaan perpustakaan & $\begin{array}{l}\text { Diselenggarakan di Perpustakaan } \\
\text { UNAIR }\end{array}$ \\
\hline 17 Desember 2011 & Pelatihan Pengolahan Buku (klasifikasi) & $\begin{array}{l}\text { Diselenggarakan di Perpustakaan } \\
\text { UNAIR }\end{array}$ \\
\hline 29-31 Oktober 2012 & $\begin{array}{lll}\begin{array}{l}\text { Pelatihan manajemen } \\
\text { perpustakaan }\end{array} & \text { dan } & \text { otomasi } \\
\end{array}$ & $\begin{array}{l}\text { Diselenggarakan di Perpustakaan } \\
\text { UNAIR }\end{array}$ \\
\hline September 2015 & $\begin{array}{l}\text { Pelatihan untuk guru dan pengelola sekolah } \\
\text { terkait sistem informasi }\end{array}$ & $\begin{array}{l}\text { Kerjasama dengan Pimpinan } \\
\text { Wilayah Muhammadiyah } \\
\text { (PWM) Jawa Timur, } \\
\text { diselenggarakan di } \\
\text { Kantor Pimpinan Wilayah } \\
\text { Muhammadiyah Jawa Timur, jalan } \\
\text { Kerto Menanggal Surabaya. }\end{array}$ \\
\hline 09-11 Februari 2016 & $\begin{array}{l}\text { Peningkatan Kompetensi Pengelolaap } \\
\text { Perpustakaan }\end{array}$ & $\begin{array}{l}\text { Bekerjasama dengan Lembaga } \\
\text { Pendidikan Tenaga Kependidikan } \\
\text { (LPTK) diselenggarakan di Aula } \\
\text { MAN Karanganyar Paiton } \\
\text { Kabupaten Probolinggo }\end{array}$ \\
\hline 6 Maret 2018 & Manajemen Perpustakaan Digital & $\begin{array}{l}\text { Diselenggarakan di Perpustakaan } \\
\text { UNAIR dalam rangka peringatan } \\
\text { Dies Natalis Perpustakaan ke-63 }\end{array}$ \\
\hline 23 April 2019 & Manajemen Perpustakaan Digital & $\begin{array}{l}\text { Diselenggarakan di Perpustakaan } \\
\text { UNAIR dalam rangka peringatan } \\
\text { Dies Natalis Perpustakaan ke-64 }\end{array}$ \\
\hline
\end{tabular}

Ide diadakan pelatihan manajemen perpustakaan sekolah adalah untuk mewujudkan perpustakaan sebagai sumber belajar bagi guru dan siswa yang mampu mendukung pelaksanaan kurikulum yang sedang berlangsung, dalam rangka mencerdaskan kehidupan bangsa.

\section{SDG 3: GOOD HEALTH AND WELL-BEING} Akses Layanan Informasi dan Edukasi

Sebagai salah satu support system lembaga, perpustakaan menyediakan sumber informasi dan mendesiminasikan karya ilmiah sivitas akademika UNAIR, baik bagi Siva UNAIR maupun bagi masyarakat umum. Pendidikan memang termasuk di antara tugas perpustakaan modern, salah satu tujuan barunya adalah pendidikan yang diadopsi pada Konferensi PBB tentang Lingkungan dan Pembangunan di Rio de Janeiropada tahun 1992 (Perserikatan Bangsa-Bangsa, 1992), adalah dokumen internasional besar pertama yang mewajibkannegara untuk memperkenalkan ESDatau Education for sustainable development ke dalam berbagai sistem pendidikan.

Langkah selanjutnya didiseminasi ESD adalah perintah PBB tahun 2005 dan 2015, ESD memberdayakan pelajar untuk mengambil keputusan yang tepat dan bertanggung jawabtindakan untuk integritas lingkungan, kelangsungan ekonomi dan masyarakat yang adil, untuk saat ini dangenerasi mendatang, dengan tetap menghormati keragaman budaya. ESD berisikan tentang pembelajaran seumur hidup danmerupakan bagian tak terpisahkan dari 
pendidikan yang bermutu.ESD bersifat holistik dan transformasional pendidikan yang membahas konten dan hasil pembelajaran, pedagogi dan pembelajar hidup dengan tujuan dengan mengubah masyarakat (UNESCO, 2019).

Program kerja perpustakaan terkait dengan pemanfaatan akses layanan informasi dan edukasi yang bertujuan sebagai pembelajaran seumur hidup adalah:

1. Diseminasi karya ilmiah (Institutional Repository)

Berdasarkan Peraturan Rektor Universitas Airlangga Nomor 46 Tahun 2016 tentang Wajib Serah Simpan Karya Ilmiah di Lingkungan Universitas Airlangga, perpustakaan melakukan pendokumentasian dan penyebaran informasi karya ilmiah Universitas Airlangga secara tersistem dan berkesinambungan. Maka dibangunlah seperangkat layanan untuk mengumpulkan, menyimpan, melestarikan, dan menyebarkan koleski dalam format digital yang dihasilkan oleh sivitas akademika UNAIR yang disebut dengan Instutional Repository, yang dapat diakses melalui laman: http://repository.unair.ac.id/

Capaian Institutional Repository UNAIR tingkat Internasional dan Nasional:

> Kategori TRANSPARENT RANKING:

Institutional Reposity Universitas Airlangga menduduki rangking 13 Dunia.Informasi bisa diakses melalui laman: (https://repositories.webometrics.info/en/institutional).

\section{RAMA REPOSITORY}

Berdasarkan data RAMA REPOSITORY, Universitas Airlangga menempati posisi ke-2.Informasi bisa diakses melalui laman: http://rama.ristekbrin.go.id/

RAMA adalah repositori nasional laporan hasil penelitian baik berupa tugas akhir maupun proyek penelitian mahasiswa yaitu skripsi (diploma), tesis (S2), disertasi (S3), dan laporan penelitian dosen atau penelitian yang bukan merupakan publikasi di jurnal, konferensi, maupun buku yang diintegrasikan dari Repositori Perguruan Tinggi dan Lembaga Penelitian di Indonesia.

2. Peningkatan literasi informasi

a. Internal

Kegiatan literasi informasi internal ini ditujukan kepada sivitas akademika UNAIR. Beberapa kegiatan yang dilakukan dalam rangka memanfaatkan sumber informasi perpustakaan adalah:

$>$ Online Research Management, merupakan salah satu program akses eResourches yang diadakan dan dikembangkan Universitas Airlangga melalui perpustakaan, bisa akses melalui website: lib.unair.ac.id

$>$ Reference Manager

$>$ Library 101

$>$ Plagiarism Ceker (Turnitin)

b. Exsternal

Perpustakaan UNAIR menyelenggarakan program peningkatan literasi informasi bagi masyarakat, diantaranya:

> Pelatihan Manajemen Perpustakaan Digital, kegiatan ini diadakan bagi pengelola perpustakaan sekolah dan Taman Baca binaan Perpustakaan UNAIR 
Storytelling, kegiatan ditujukan kepada pengelola perpustakaan/ taman baca Pendidikan Anak Usia Dini dan Taman Kanak-kanan, dalam rangka meningkatkan minat baca anak sejak usia dini.

3. Seiring dengan perkembangan teknologi informasi dan kebutuhan sumber informasi masyarakat pengguna informasi, baik sivitas akademika UNAIR maupun masyarakat umum, maka perpustakaan mengembangkan layanan online, diantaranya:

Table 3. Layanan Online Perpustakaan Unair

\begin{tabular}{|c|l|l|}
\hline No & Layanan & Laman \\
\hline 1 & Perpanjangan peminjaman buku & bit.ly/ailisstudent \\
\hline 2 & Surat bebas pinjam perpustakaan & bit.ly/bebaspinjam \\
\hline 3 & Request layanan Osiris & bit.ly/RequestOsirisUA \\
\hline 4 & Request repo & bit.ly/RepoRequestUA \\
\hline 5 & Unggah repo & bit.ly/Upl_mandiri \\
\hline 6 & Request eResources & bit.ly/penelusuranpua \\
\hline 7 & Daftar Remotexs & unair.remotexs.com/user/register \\
\hline
\end{tabular}

Informasi dapat diakses melalui Websiste Perpustakaan UNAIR: lib.unair.ac.id

\section{SDG 10: REDUCED INEQUALITIES \\ Program Rekruitmen Mahasiswa}

Perpustakaan menyelenggarakan program merekrut mahasiswa Program ini diadakan dalam rangka mendukung proses pembelajaran di lingkungan Universitas Airlangga, khususnya dalam hal manajemen perpustakaan. Program ini dilaksanakan guna memberikan kesempatan kepada mahasiswa untuk menunjukkan kemampuan dan menerapkan pengetahuan yang didapatkan di perguruan tinggi pada dunia kerja nantinya.

Table 4. Data Rekruitmen Mahasiswa:

\begin{tabular}{|c|c|c|c|c|}
\hline No & NAMA & NIM & FAKULTAS & BULAN \\
\hline \multicolumn{5}{|c|}{ TAHUN 2017} \\
\hline 1 & Dewi Rekno Ulansari & 041311466026 & FEB & Februari \\
\hline 2 & Ninik Alfiyah & 071611623003 & Fisip & Februari \\
\hline 3 & Niken Cahyani & 121411231034 & FIB & Maret \\
\hline 4 & Dewi Rekno Ulansari & 041311466026 & FEB & Juli \\
\hline 5 & Juane Haq & 151411813926 & Vokasi & Agustus \\
\hline 6 & Kuncoro & 151411313018 & Vokasi & Agustus \\
\hline 7 & Nadia Nur Afifah & 121511233068 & FIB & September \\
\hline 8 & Cicilia Habibah & 121511233076 & FIB & Oktober \\
\hline 9 & Siti Zumrotus Safiyah & 121511233070 & FIB & November \\
\hline \multicolumn{5}{|c|}{ TAHUN 2018} \\
\hline 1 & Astrifi Kurnia sari & 121511133121 & FIB & Januari \\
\hline 2 & Dinda Aprilia Rachman & 121511233075 & FIB & Januari \\
\hline 3 & Lailatul Hidayah & 121511233063 & & Mei \\
\hline 4 & Kurnia Ayu Purnawati & 121511233071 & FIB & Mei \\
\hline 5 & Firda Nindya Vionita & 071611633071 & FISIP & September \\
\hline 6 & Medya Ayu Budiarti & 071611633042 & FISIP & September \\
\hline 7 & Ditha andhini & 121511133119 & FIB & November \\
\hline 8 & Erlinda kusuma prahastiwi & 121511133104 & FIB & November \\
\hline 9 & Cecilia Anantria Cahya Kinasih & 071511633053 & FISIP & November \\
\hline 10 & Sofia Nur Aisyah & 071511633045 & FISIP & November \\
\hline \multicolumn{5}{|c|}{ TAHUN 2019} \\
\hline 1 & Tri Mahardhika & 151711313068 & Vokasi & Januari \\
\hline
\end{tabular}




\begin{tabular}{|c|c|c|c|c|}
\hline 2 & Yasmin Tsana A & 121711133105 & FIB & November \\
\hline 3 & Rosa Rif'atin & 121711133063 & FIB & November \\
\hline \multicolumn{5}{|c|}{ TAHUN 2020} \\
\hline 1 & Aditya Catur Pratama Putra & 121611133089 & FIB & Peb - Maret \\
\hline 2 & Aldi Dwi Pranyata Anjasmara & 151711313017 & Vokasi & Peb - Maret \\
\hline 3 & Faisal Adi lrawan & 131811133062 & FKP & Peb - Maret \\
\hline 4 & F ebri Tri Rasyiid & 081611733005 & FST & Peb - Maret \\
\hline 5 & Halimaha Bagas Kuswna N & 111811133001 & Psikologi & Peb - Maret \\
\hline 6 & Hariawan Widi Nugroho & 081811833054 & FST & Peb - Maret \\
\hline 7 & Muchammad Anam Saputra & 121711133066 & FIB & Peb - Maret \\
\hline 8 & RofLk Ainun Najid & 081611333092 & FST & Peb - Maret \\
\hline 9 & Wendi Genta Perkasa & 131811133050 & FKP & Peb - Maret \\
\hline 10 & Yoga Apriliyan Pamungkas & 151711313055 & Vokasi & Peb - Maret \\
\hline
\end{tabular}

\section{SDG 17: PARTNERSHIPS FOR THE GOALS \\ Kerjasama Antar Perpustakaan}

Dalam rangka mengembangkan dan berbagi sumber informasi ke sivitas akademika UNAIR dan perguruan tinggi lainnya, Perpustakaan Universitas Airlangga berkolaborasi dengan perpustakaan lain. Didukung secara memadai dalam hal konektivitas, sumber daya dan kerangka hukum, perpustakaandapat memberikan kontribusi nyata bagi pembangunan dengan menyediakan akses informasi.

Bentuk kerjasama yang dilakukan Perpustakaan UNAIR:

a. Dalam Negeri

$>$ Forum Kerjasama Perpustakaan PerguruanTinggi Negeri (FKP2TN)

Laman: http://www.fkp2tn.org/

$>$ Forum PerpustakaanPerguruanTinngi Indonesia (FPPTI) JawaTimur

Laman: https://fppti-jatim.or.id/public/

b. Luar Negeri

ASEAN University Network Inter-Library Online (AUNILO),

ASEAN University Networks Inter Library Online (AUNILO) merupakan salah satu inisiatif yang muncul dari ASEAN University Network (AUN). Sebagai upaya memperkokoh ASEAN University Network (AUN), AUNILO mendorong penggunaan teknologi informasi dan komunikasi di bidang pendidikan melalui program jejaring informasi. Tujuan UNAIR berkabung dengan AUNILO memberikan manfaat yang besar bagi seluruh masyarakat akademik dan stakeholders, dalam hal untuk meningkatkan tukar informasi antar universitas yang terlibat dalam kolaborasi. Informasi lebih lanjut akses melalui laman: https://aunilo.net/

American Corner

Melalui Universitas Airlangga sejak tahun 2003 perpustakaan melakukan kerjasama dengan Kedutaan Besar Amerika di Surabaya, yaitu dalam bentuk layanan American Corner. American Corner ini menyediakan sumber informasi bagi sivitas akademika dan masyarakat terkait dengan sumber informasi tentang masyarakat, budaya, dan politik Amerika Serikat. Mulai tahun 2020 di American Corner ini, dibuka layanan USA Education/ 


\section{$>$ AUSI Corner}

AUSI Corner di Perpustakaan didirikan pada tahun 2019, merupakan bentuk kerjasama dengan Kedutaan Australia. Sama halnya dengan American Corner, AUSI Corner menyediakan sumber informasi tentang Australia, dan beberapa kegiatan diskusi dengan para tohoh, akademisi dari negara Australia

Pada tingkat global, peprustakaan adalah tulang punggung sistem inovasi, mendukung penelitian yang memungkinkanuntuk pengambilan keputusan yang lebih baik di pemerintahan dan organisasi internasional. Di tingkat lokalperpustakaan menyediakan ruang yang aman dan berfokus pada komunitas bagi pengguna untuk mengakses dan meletakkan informasiuntuk bekerja dengan cara yang harmoni (International Federation of Library Associations and Institutions (IFLA), 2019)

\section{PENUTUP}

\section{KESIMPULAN}

Dimasa depan Perpustakaan selalu membutuhkan solusi kreatif dalam menjalankan peran dan tantangan baru seperti pengembangan yang terjadi secara bertahap dengan indikator keberhasilan untuk melacak dan memantau kemajuan, menggunakan platform media sosial sebagai sarana saat ini; perpustakaan UNAIR berkolaborasi dengan perpustakaan lain untuk menyebarkan informasi. Perpustakaan UNAIR Memberikan pelatihan literasi informasi untuk memberdayakan individu, infrastruktur dan kapasitas seperti layanan internet untuk akses tak terbatas ke informasi dan memberikan kesempatan untuk literasi digital. Perpustakaan UNAIR membuat jaringan kolaboratif atau groupware yang mengaktifkan pertukaran informasi yang terkait dengan SDGs. Perpustakaan UNAIR juga mengembangkan platform kelembagaan situs web tempat informasi tentang SDGs dapat diakses bersama, kolaborasi yang lebih besar dari pustakawan dengan profesional di semua bidang penelitian untuk membantu memecahkan masalah social, lokal dan nasional komunitas pemustaka.

\section{SARAN}

Perpustakaan UNAIR menciptakan kesadaran melalui jejaring sosial, Perpustakaan dimasa depan diharapkan berfungsi melampaui praktik konvensional untuk dicapai dampak yang lebih besar dalam mewujudkan SDGs. Kolaborasi dengan organisasi lain, lembaga dan badan profesi masih sangat diperlukan. Pada tahun 2030, Perpustakaan diakui sebagai kendaraan utama dalam proses pembelajaran seumur hidupyang diwijudkan melalui SDGs dimasa mendatang. 


\section{DAFTAR PUSTAKA}

Anasi, S. N., Ukangwa, C. C., \& Fagbe, A. (2018). University libraries-bridging digital gaps and accelerating the achievement of sustainable development goals through information and communication technologies. World Journal of Science, Technology and Sustainable Development, 15(1), 13-25. https://doi.org/10.1108/wjstsd-11-2016-0059

Fatmawati, E. (2018). Multi-Kompetensi Perpustakaan dalam Mendukung Pembangunan Nasional. Jurnal Perpustakaan Pertanian, $27(1), \quad 1$. https://doi.org/10.21082/jpp.v27n1.2018.p1-6

Fedorowicz-Kruszewska, M. (2020). Environmental education in libraries - theoretical foundations and practical implementation. Library Management, 41(4-5), 279-293. https://doi.org/10.1108/LM-12-2019-0087

Hayes, H. (2004). The role of libraries in the knowledge economy. Serials: The Journal for the Serials Community, 17(3), 231-238. https://doi.org/10.1629/17231

International Federation of Library Associations and Institutions (IFLA). (2019). Development and Access to Information 2019.

Koentjaraningrat.1983. Metode-Metode Penelitian Masyarakat.Gramedia. Jakarta

Krolak, L. (2006). Background paper* prepared for the Education for All Global Monitoring Report 2006 The role of libraries in the creation of literate environments The Role of Libraries in the Creation of Literate Environments. International Journal of Adult and Lifelong Education, 4(1/4), 5. https://www.ifla.org/files/assets/literacy-andreading/publications/role-of-libraries-in-creation-of-literate-environments.pdf

Nasrullah, R., Aditya, W., Satya, T. I., Nento, M. N., Hanifah, N., Miftahussururi, \& Akbari, Q. S. (2017). Materi Pendukung Literasi Digital: Gerakan Literasi Nasional. Kementerian Pendidikan Dan Kebudayaan Jakarta, 33. https://gln.kemdikbud.go.id/glnsite/wp-content/uploads/2017/10/cover-materipendukung-literasi-finansial-gabung.pdf

Rufaidah, V. W., \& Iskak, P. I. (2019). Peran Pusat Perpustakaan Dan Penyebaran Teknologi Pertanian (Pustaka) Kementan Dalam Tujuan Pembangunan Berkelanjutan. Journal Of Documentation And Information Science, 3(1), 45-56.

Shafack, R. M. (2016). The Library and Information Science (LIS) Profession and the Cameroon Development Vision 2035: A Perception Study. Journal of Sustainable Development, 9(4), 225. https://doi.org/10.5539/jsd.v9n4p225

Voituriez, T., Morita, K., Giordano, T., Bakkour, N., \& Shimizu, N. (2017). Financing the 2030 agenda for sustainable development. Governing Through Goals: Sustainable Development Goals as Governance Innovation, 16301(October), 259-273. https://doi.org/10.7551/mitpress/9780262035620.003.0011

IFLA (2018), The International Advocacy Programme (IAP), available at: https://www.ifla.org/ldp/iap (accessed 23 November 2019)

UNESCO (2019), "What is education for sustainable development?", available at: https://en.unesco.org/ themes/education-sustainable-development/what-is-esd 